\title{
The effect of choline and cystine on the utilisation of methionine for protein accretion, remethylation and trans-sulfuration in juvenile shrimp Penaeus monodon
}

\author{
Lenaïg Richard ${ }^{1,2}$, Christiane Vachot $^{1}$, Anne Surget ${ }^{1}$, Vincent Rigolet ${ }^{2}$, Sadasivam J. Kaushik ${ }^{1}$ \\ and Inge Geurden ${ }^{1 *}$ \\ ${ }^{1}$ INRA, UR 1067 NuMeA Nutrition, Metabolism and Aquaculture, F-64310 Saint-Pée-sur-Nivelle, France \\ ${ }^{2}$ UNIMA (AQUALMA), BP 93 Immeuble SCIM, 4 rue Galliéni, Mahajanga 401, Madagascar
}

(Received 29 September 2010 - Revised 27 January 2011 - Accepted 8 February 2011 - First published online 31 May 2011)

\section{Abstract}

This 35-d feeding experiment examined in juvenile shrimp Penaeus monodon ( $3.3 \mathrm{~g}$ initial body weight) the effects of methionine (Met), choline and cystine on protein accretion and the activity of two key enzymes of remethylation (betaine-homocysteine methyltransferase; BHMT) and trans-sulfuration (cystathionine $\beta$-synthase; CBS). The interaction between Met and choline was tested using semi-purified diets either adequate or limiting (30 or $50 \%$ ) in total sulphur amino acid (SAA) content with a constant cystine:Met ratio. The diets contained either basal or excess choline ( $3 v .7 \mathrm{~g} / \mathrm{kg}$ feed). Cystine was added to two other 30 and $50 \%$ Met-limiting diets to adjust the SAA supply to that of the control diet in order to evaluate the interaction between Met and cystine. As expected, N accretion was significantly lower with the SAA-limiting diets but increased back to control levels by the extra choline or cystine, demonstrating their sparing effect on Met utilisation for protein accretion. We show, for the first time, the activities of BHMT and CBS in shrimp hepatopancreas. Only BHMT responded to the SAA deficiencies, whereas the extra choline and cystine did not stimulate remethylation or down-regulate trans-sulfuration. Our data also suggest the capacity of $P$. monodon to synthesise taurine, being significantly affected by the cystine level in the $30 \%$ SAA-limiting diets. Further research is warranted to better understand the metabolic regulation of taurine synthesis in shrimp and of the observed Met-sparing effects.

Key words: Crustaceans: Sulphur amino acids: Methionine utilisation: Methionine sparing: Taurine

The marine black tiger shrimp Penaeus monodon is the world's second most cultured crustacean species ${ }^{(1)}$. For crustacean shrimp, as for farmed finfish, plant protein sources are increasingly included in feeds in order to reduce the reliance on wild-caught marine protein sources. However, the replacement of fish or shrimp meal by plant protein sources changes the amino acid (AA) profile of the diet, with methionine (Met) as one of the first-limiting essential $\mathrm{AA}^{(2,3)}$. In $P$. monodon fed an optimal crude protein level, we have previously noted that a $30 \%$ Met deficiency diminished protein accretion $^{(4)}$ and increased deamination ${ }^{(5)}$, suggesting a change in AA catabolism in shrimp receiving an imbalanced dietary Met supply. In P. monodon, or crustacean species in general, not much is known on the metabolic utilisation of Met besides its need for protein synthesis. In contrast, the importance of Met as a methyl-group donor for methylation reactions and as a precursor of other sulphur-containing compounds, such as cysteine or taurine, is well recognised in vertebrates ${ }^{(6-10)}$. As such, homocysteine (Hcy), at the branch point of the three major pathways of Met metabolism (transmethylation, remethylation and transsulfuration), is often regarded as a regulatory component of Met metabolism since Hcy can be either trans-sulfurated for cysteine production (catalysed by cystathionine $\beta$-synthase; CBS) or remethylated into Met. In the rat liver, the remethylation of Hcy into Met occurs by two different pathways using either the folate-vitamin $\mathrm{B}_{12}$-dependent enzyme methionine synthase (MS) or the betaine-homocysteine methyltransferase (BHMT) ${ }^{(9)}$, which appear to contribute equally to the regeneration of $\mathrm{Met}^{(11)}$

We have recently evaluated the Met requirement for maximal protein gain in $P$. monodon to be $0.56 \mathrm{~g} / \mathrm{kg}$ body weight

Abbreviations: AA, amino acids; BHMT, betaine-homocysteine methyltransferase; CBS, cystathionine $\beta$-synthase; CC, choline chloride; CTL, control diet; Cyss, cystine; DEF30, $30 \%$ Met- or sulphur amino acid-limiting diet; DEF50, 50\% Met- or sulphur amino acid-limiting diet; DGC, daily growth coefficient; Hcy, homocysteine; Met, methionine; MS, methionine synthase; SAA, total sulphur amino acids.

*Corresponding author: I. Geurden, fax +33 559545152, email inge@st-pee.inra.fr 
per $\mathrm{d}$, corresponding to a dietary level of $0 \cdot 8 \% \operatorname{Met}(\% \mathrm{DM})^{(4)}$. This value is close to the Met requirement value of $0.9 \%$ found for post-larval $P$. monodon ${ }^{(12)}$, but lower than the $1.3-1 \cdot 4 \%$ Met requirement values reported for juvenile $P$. monodon ${ }^{(13)}$ or kuruma shrimp Marsupenaeus japonicus ${ }^{(14,15)}$. The total sulphur amino acid (SAA) requirements estimated at $1.1 \%$ $(0.8 \% \mathrm{Met})$ by us in an earlier study ${ }^{(4)}$ and $1.3 \%(0.9 \% \mathrm{Met})$ by Millamena et al. ${ }^{(12)}$ included 0.3 and $0.4 \%$ of cystine, respectively. Little attention has been paid to the interaction between dietary Met and cyst(e)ine when determining Met requirements in shrimp, despite the ample evidence of the Met-sparing effect of cystine in vertebrates such as tele$\operatorname{osts}^{(2,16,17)}$, birds ${ }^{(18,19)}$ or mammals ${ }^{(20,21)}$, where $50 \%$ or more of the requirement for Met can be covered by a dietary supply of cystine.

Dietary choline has been found to improve growth, providing free methyl groups ${ }^{(22-24)}$, thus exerting a sparing effect on Met utilisation ${ }^{(15,23,25)}$. As BHMT is directly involved in the remethylation of Met through betaine, this enzyme is suggested to have a dual role: in the catabolism of choline (betaine) and/or the conservation of Met depending on the dietary level of $\mathrm{Met}^{(25)}$.

For crustaceans, there is no information on the nutritional regulation of enzymes involved in SAA metabolism. In the present study, we examined the potential sparing effect of dietary choline and cystine on the utilisation of Met for protein accretion in juvenile shrimp $P$. monodon and their effect on the activity of two enzymes of Met metabolism involved in remethylation (BHMT) and trans-sulfuration (CBS).

\section{Materials and methods}

We investigated in shrimp the Met-sparing effect (i) of dietary choline when Met was either adequate (control diet; CTL) or limiting (30 and 50\%) in the diet (diets CTL, CTL + choline chloride (CC), 30\% Met- or sulphur amino acid-limiting diet (DEF30), DEF30 + CC, 50\% Met- or sulphur amino acidlimiting diet (DEF50) and DEF50 + CC) and (ii) of cystine added to the 30 and 50\% Met-limiting diets (diets DEF30, DEF30 + cystine (Cyss), DEF50 and DEF50 + Cyss). The first series of the diets was formulated to contain decreasing levels of SAA with a constant cystine:Met ratio. The second series contained similar levels of total SAA by modifying the cystine:Met ratio.

\section{Experimental diets}

We formulated eight semi-purified isonitrogenous diets to supply three dietary SAA levels and two choline levels (Tables 1 and 2). The dietary crude protein level was based on our previous study with juvenile $P$. monodon ${ }^{(4)}$ and formulated to be $35 \%$ crude protein as fed (38\% diet DM). N was supplied by casein and a crystalline AA blend at a ratio of 43:57 (Table 1). The diets were manufactured by Institut National de la Recherche Agronomique at the experimental facility of Donzacq (Donzacq, France). The crystalline AA blend was coated with $2 \%$ agar dissolved in warm water $\left(\mathrm{pH} 7,40^{\circ} \mathrm{C}\right)$. Glucosamine and fish protein-soluble
Table 1. Formulation of the experimental semi-purified diets fed to juvenile Penaeus monodon for 5 weeks

\begin{tabular}{|c|c|}
\hline Ingredients ( $\mathrm{g} / \mathrm{kg}$ diet) & Diets \\
\hline Basal mixture* & 621 \\
\hline Caseint & 160 \\
\hline AA mixture & 212 \\
\hline Arg HCl & $31 \cdot 7$ \\
\hline His $\mathrm{HCl} \ddagger$ & 3.4 \\
\hline lleł & $6 \cdot 4$ \\
\hline Leuł & $12 \cdot 5$ \\
\hline Lys§ & 7.5 \\
\hline DL-Met§ & $0.1-4 \cdot 4 \|$ \\
\hline Phe & 6.9 \\
\hline Thr $\ddagger$ & $7 \cdot 2$ \\
\hline Try $\ddagger$ & $2 \cdot 4$ \\
\hline Valf & $5 \cdot 8$ \\
\hline Alat & $16 \cdot 2$ \\
\hline Asp $\ddagger$ & $25 \cdot 6$ \\
\hline Cyss $\ddagger$ & $1 \cdot 2-7 \cdot 2 \|$ \\
\hline Gluł & 24.5 \\
\hline Gly† & $23 \cdot 9$ \\
\hline Proł & 20.5 \\
\hline Ser $\ddagger$ & $4 \cdot 8$ \\
\hline Tyrł & $5 \cdot 2$ \\
\hline Choline chloride† & $0-7$ \\
\hline
\end{tabular}

AA, amino acids.

* Basal mixture supplied (in $\mathrm{g} / \mathrm{kg}$ diet as fed): gelatinised starch, 310; fish oil, 59; soya lecithin, 20; sodium alginate, 49; cellulose, 20; agar, 20; stabilised cholesterol, 15; fish protein concentrate (CPSP 90), 20; D-glucosamine $98 \% \mathrm{HCl}, 8$; mineral mixture, 50; vitamin mixture, 50 . Mineral and vitamin mixtures were as presented in Richard et al. ${ }^{(4,5)}$ and supplied $167 \mathrm{~g} / \mathrm{kg}$ mixture of choline chloride $(60 \%)$.

† Acros (Illkirch, France); $95 \%$ pure casein (CAS 9000-71-9).

$\ddagger$ Jerafrance (Jeufosse, France).

$\S$ Eurolysine (Paris, France).

|| The crystalline AA mixture supplied methionine (Met) at $4.5,2.3$ and $0.1 \mathrm{~g} / \mathrm{kg}$ feed and cystine (Cyss) at 2.9, 2.0 and $1.2 \mathrm{~g} / \mathrm{kg}$ feed in the control, 30 and $50 \%$ Met-limiting diets, respectively. For the Cyss-enriched diets, the AA mixture supplied 5.1 and $7.2 \mathrm{~g} / \mathrm{kg}$ feed in the 30 and $50 \%$ Met-limiting diets, respectively. An increase in the amount of non-essential AA compensated for varying Met and Cyss levels.

I Choline chloride (99\%) was supplemented at $7 \mathrm{~g} / \mathrm{kg}$ feed in the choline-enriched diets. Gelatinised starch (in basal mixture) compensated for the choline addition.

concentrate (CPSP 90) were added to improve feed palatability. Casein, cholesterol, soyabean lecithin, sodium alginate, cellulose, CPSP 90, starch, glucosamine, minerals and vitamins were first mixed together and homogenised before adding the coated AA, fish oil and CC. After thorough mixing, feed was pelleted $(3 \mathrm{~mm})$, dried at $40^{\circ} \mathrm{C}$ and shipped to the experimental facility in Madagascar, where it was stored at $4{ }^{\circ} \mathrm{C}$.

Study of the methionine-sparing effect of choline. We formulated three diets to be adequate (diet CTL) or 30 or $50 \%$ limiting in Met (diets DEF30 and DEF50, respectively). In these diets (CTL, DEF30 and DEF50), the ratio of cystine:Met was kept constant at $0 \cdot 4$, so that total SAA levels decreased according to the Met level (from 1.2 to $0.6 \mathrm{~g} / 100 \mathrm{~g} \mathrm{DM}$; Table 2). The adequate Met level $(0.8 \mathrm{~g} / 100 \mathrm{~g}$ DM) corresponds to the requirement value determined in our previous study $^{(4)}$. We formulated three supplemental diets (CTL + CC, DEF30 + CC and DEF50 + CC) to supply choline in excess $(7000 \mathrm{mg} / \mathrm{kg}$ dry feed). CC, an efficient choline source in shrimp ${ }^{(15)}$, was used in the diets. The basal level of choline in the diet was $3000 \mathrm{mg} / \mathrm{kg} \mathrm{DM}$, as in our previous study ${ }^{(4)}$.

Study of the methionine-sparing effect of cystine. We used the same two diets as described previously (DEF30 and 
Table 2. Analysed chemical composition of the experimental semi-purified diets fed to juvenile Penaeus monodon for 5 weeks

\begin{tabular}{|c|c|c|c|c|c|c|c|c|}
\hline & \multicolumn{8}{|c|}{ Diets } \\
\hline & CTL & $C T L+C C$ & DEF30 & $\mathrm{DEF} 30+\mathrm{CC}$ & DEF50 & DEF50 + CC & DEF30 + Cyss & DEF50 + Cyss \\
\hline DM (\% diet) & $89 \cdot 6$ & $90 \cdot 1$ & $90 \cdot 6$ & $90 \cdot 2$ & $90 \cdot 2$ & $90 \cdot 1$ & 90.5 & $90 \cdot 1$ \\
\hline Crude protein $(\mathrm{N} \times 6.25, \% \mathrm{DM})$ & 37.5 & 38.4 & $37 \cdot 7$ & 38.3 & 38 & $38 \cdot 1$ & $37 \cdot 8$ & $38 \cdot 7$ \\
\hline Crude fat $(\%$ DM) & 8.5 & 8.9 & $10 \cdot 3$ & $9 \cdot 7$ & 9.9 & 9 & $9 \cdot 1$ & $8 \cdot 7$ \\
\hline Ash (\% DM) & 5.9 & $6 \cdot 0$ & 5.9 & $6 \cdot 0$ & 5.9 & 5.9 & 5.8 & $6 \cdot 0$ \\
\hline Gross energy (kJ/g DM) & 19.8 & $19 \cdot 8$ & $19 \cdot 8$ & $19 \cdot 7$ & 19.9 & 19.8 & $19 \cdot 8$ & $19 \cdot 7$ \\
\hline Choline (\% DM) & 0.34 & 0.75 & 0.29 & 0.74 & 0.34 & 0.71 & 0.28 & 0.21 \\
\hline \multicolumn{9}{|l|}{ Amino acids (g/kg DM) } \\
\hline Arg & $46 \cdot 4$ & $45 \cdot 6$ & 43.5 & $43 \cdot 9$ & $44 \cdot 1$ & $46 \cdot 6$ & $43 \cdot 3$ & $48 \cdot 2$ \\
\hline His & $7 \cdot 1$ & $5 \cdot 7$ & $6 \cdot 0$ & 5.9 & $6 \cdot 3$ & $7 \cdot 0$ & $6 \cdot 1$ & $7 \cdot 0$ \\
\hline Ile & 14.5 & 14.5 & $12 \cdot 9$ & $13 \cdot 5$ & $12 \cdot 7$ & $14 \cdot 7$ & $13 \cdot 3$ & 14.5 \\
\hline Leu & $26 \cdot 1$ & $25 \cdot 9$ & 23.0 & $23 \cdot 7$ & 23.8 & 26.5 & 23.6 & $26 \cdot 6$ \\
\hline Lys & $22 \cdot 9$ & $22 \cdot 7$ & $20 \cdot 2$ & $21 \cdot 1$ & $21 \cdot 0$ & $22 \cdot 4$ & 20.5 & $22 \cdot 0$ \\
\hline Met & $8 \cdot 3$ & $8 \cdot 3$ & $5 \cdot 6$ & 5.9 & $4 \cdot 2$ & 4.4 & $5 \cdot 8$ & 4.5 \\
\hline Phe & $14 \cdot 8$ & 14.5 & 11.8 & $13 \cdot 4$ & 13.5 & 14.9 & $12 \cdot 9$ & $15 \cdot 0$ \\
\hline Thr & $15 \cdot 6$ & $15 \cdot 3$ & $13 \cdot 9$ & $14 \cdot 2$ & $14 \cdot 3$ & $15 \cdot 2$ & $14 \cdot 0$ & $15 \cdot 5$ \\
\hline Val & $16 \cdot 3$ & $15 \cdot 7$ & $16 \cdot 6$ & 14.8 & $13 \cdot 4$ & $15 \cdot 3$ & $15 \cdot 1$ & $15 \cdot 5$ \\
\hline Ala & $23 \cdot 3$ & $22 \cdot 7$ & 21.5 & $22 \cdot 0$ & 22.5 & $23 \cdot 6$ & $20 \cdot 3$ & $23 \cdot 4$ \\
\hline Asp & $37 \cdot 0$ & $35 \cdot 6$ & 34.7 & 34.8 & 35.5 & 36.9 & $32 \cdot 7$ & 35.5 \\
\hline Cyss & 3.4 & $3 \cdot 2$ & 2.6 & $2 \cdot 7$ & 1.8 & 1.7 & 5.4 & $7 \cdot 2$ \\
\hline Glu & $55 \cdot 7$ & $54 \cdot 2$ & $51 \cdot 2$ & $52 \cdot 3$ & $54 \cdot 0$ & $56 \cdot 9$ & $50 \cdot 3$ & $54 . \overline{6}$ \\
\hline Gly & $27 \cdot 4$ & $27 \cdot 4$ & $26 \cdot 3$ & $26 \cdot 3$ & 26.5 & 28.0 & 25.9 & $27 \cdot 8$ \\
\hline Pro & $38 \cdot 7$ & $37 \cdot 6$ & 33.6 & 34.0 & $35 \cdot 8$ & 38.4 & $33 \cdot 3$ & $39 \cdot 1$ \\
\hline Ser & $13 \cdot 0$ & 12.9 & $12 \cdot 2$ & $12 \cdot 6$ & $12 \cdot 7$ & 13.5 & $12 \cdot 1$ & $13 \cdot 0$ \\
\hline Tyr & $14 \cdot 2$ & $14 \cdot 0$ & $12 \cdot 4$ & $12 \cdot 9$ & $12 \cdot 6$ & $13 \cdot 8$ & $13 \cdot 6$ & $16 \cdot 0$ \\
\hline Cyss:Met ratio & 0.4 & 0.4 & 0.5 & 0.5 & 0.4 & 0.4 & 0.9 & 1.6 \\
\hline Total SAA supply (\% DM) & 1.2 & $1 \cdot 1$ & 0.8 & 0.9 & 0.6 & 0.6 & 1.1 & 1.2 \\
\hline
\end{tabular}

DEF50). In two other diets, Cyss was added in excess (DEF30 + Cyss and DEF50 + Cyss) in order to adjust the total SAA supply to that of the diet CTL $(1 \cdot 1-1.2 \mathrm{~g} / 100 \mathrm{~g}$ $\mathrm{DM})$. In these diets, the cystine:Met ratios were 0.9 for diet DEF30 + Cyss and 1.6 for diet DEF50 + Cyss.

\section{Animal husbandry}

Juvenile P. monodon (3.3 (0.1) g; Aqualma hatchery, Madagascar) were reared in circular 150 litre fibreglass-covered tanks (fifteen shrimp per tank) for 5 weeks, following a $7 \mathrm{~d}$ adaptation period during which they were fed the CTL diet at $3.5 \%$ biomass/d. For each diet, four replicate groups were used. Average temperature, oxygen concentration, $\mathrm{pH}$ and salinity of the water were, respectively, $29 \cdot 8 \pm 1 \cdot 2^{\circ} \mathrm{C}, 6 \cdot 1$ (SD $0.4) \mathrm{mg} / 1,8.0$ (SD 0.1) and 35.0 (SD 0.5) g/l. Water was exchanged on a daily basis, at a minimum of $40 \%$ for each tank.

The shrimp were fed ad libitum four times per d (08.00, 13.00, 18.00 and 23.00 hours) using three circular trays in each tank. After $2 \mathrm{~h}$, feed was removed, and the left-over was carefully collected and stored at $-20^{\circ} \mathrm{C}$. Weekly apparent DM intake was calculated after drying the uneaten feed to a constant weight $\left(48 \mathrm{~h}, 90^{\circ} \mathrm{C}\right)$. Every week, biomass of each tank was weighed. Mortality was checked daily, and dead shrimp were removed and weighed. Shrimp in ecdysis were not considered for final sampling. A representative sample of $12 \mathrm{~h}$ feed-deprived shrimp was taken at the start (twentyfive shrimp) and the end of the experiment (five shrimp from each of the four replicate tanks per dietary treatment) for whole-body composition analysis. All samples were kept at $-20^{\circ} \mathrm{C}$ before analyses. Feed and whole carcasses were analysed for $\mathrm{DM}\left(105^{\circ} \mathrm{C}, 24 \mathrm{~h}\right)$, ash $\left(550^{\circ} \mathrm{C}, 12 \mathrm{~h}\right)$ and crude protein $(\mathrm{N} \times 6.25$, Kjeldahl Nitrogen Analyser 2000; Fison Instruments, Milan, Italy). Feed samples were analysed for choline content at the laboratory IPL (Bordeaux, France). Daily growth coefficient (DGC, \%) was calculated as: $\left.\left(W_{\mathrm{f}}^{03333}-W_{\mathrm{i}}^{0.3333}\right) / \Delta t\right) \times 100$, where $W_{\mathrm{i}}$ and $W_{\mathrm{f}}$ are the mean initial and final body weights $(\mathrm{g})$, respectively, and $\Delta t$ is the duration of the growth trial $(35 \mathrm{~d})$. N gain $(\mathrm{mg} / \mathrm{shrimp}$ per $\mathrm{d})$ was calculated as $\left(\left(\mathrm{N}_{\mathrm{f}} \times W_{\mathrm{f}}\right)-\left(\mathrm{N}_{\mathrm{i}} \times W_{\mathrm{i}}\right)\right) / \Delta t \times 1000$, where $N_{i}$ and $N_{f}$ are the $N$ content of shrimp at the start and the end of the experiment $(\mathrm{g} / 100 \mathrm{~g}$ fresh matter).

\section{Enzyme activities}

Tissue sampling and preparation. At sampling days, the shrimp were allowed to eat for $1 \mathrm{~h}$ before the excess feed was removed from the tank. At $3 \mathrm{~h}$ after feed removal, shrimp were sampled; hepatopancreas were quickly dissected out, immediately weighed and frozen in dry ice before stocking at $-80^{\circ} \mathrm{C}$. Frozen tissues were homogenised in ten volumes of ice-cold phosphate buffer $(0.04 \mathrm{M}, \mathrm{pH} 7.4,1 \mathrm{~mm}-$ EDTA, 1 mm-dithiothreitol) with Ultra-Turrax (16000 rpm). The homogenates were centrifuged at $1000 \mathrm{~g}\left(4^{\circ} \mathrm{C}\right.$ for $10 \mathrm{~min})$. The supernatant fraction was then centrifuged at $45000 \mathrm{~g}\left(4^{\circ} \mathrm{C}\right.$ for $\left.20 \mathrm{~min}\right)$. Samples were analysed for BHMT (EC 2.1.1.5) and CBS (EC 4.2.1.22) activities. Protein content of the hepatopancreas was determined by the Bradford 
method with bovine serum albumin as the standard. From the preliminary results, we determined the optimal protein concentration to be $1 \mathrm{mg}$ protein per tube for the determination of both BHMT and CBS activities, and the sample volume to be added in each tube was adjusted to this protein concentration.

Determination of the enzyme activity. Measurements of BHMT activity were based on Finkelstein \& Mudd ${ }^{(26)}$ and Lambert et al. ${ }^{(27)}$. The following compounds were incubated for $90 \mathrm{~min}$ at $37^{\circ} \mathrm{C}$ in a volume of $467.5 \mu \mathrm{l}: 37.5 \mu \mathrm{l}$ of 466.6 mm-potassium phosphate buffer ( $\mathrm{pH} \mathrm{7.4);35 \mu l} \mathrm{of}$ $100 \mathrm{~mm}-\mathrm{DL}-\mathrm{Hcy}$ (Sigma-Aldrich, Saint-Quentin Fallavier, France); $55 \mu \mathrm{l}$ of $59 \mathrm{~mm}$-betaine ${ }^{14} \mathrm{CH}_{3}$ (ARC, Isobio, Fleurus, Belgium) at $2500 \mathrm{~Bq}$. The volume of each tissue extract was adjusted according to its protein concentration and homogenisation buffer (0.04 mm-potassium phosphate buffer, $\mathrm{pH} 7 \cdot 4$, $1 \mathrm{~mm}$-EDTA and $1 \mathrm{~mm}$-dithiothreitol) was added to compensate the volume if necessary. After incubation, the reaction was stopped by adding $62.5 \mu \mathrm{l}$ of cold water and $280 \mu \mathrm{l}$ of the mixture were pipetted into a $10 \mathrm{ml}$ polypropylene column $(0.8 \times 4 \mathrm{~cm}$; Biorad, Marnes-la-Coquette, France $)$ containing $2.5 \mathrm{ml}$ of Dowex ${ }^{\circledR}$ ion exchange resin $\left(1 \times 4\left(\mathrm{Cl}^{-}\right)\right.$, 200-400 mesh; Sigma Aldrich). The non-converted betaine was eluted with $10 \mathrm{ml}$ of water, and the labelled products were eluted with $10 \mathrm{ml}$ of $1 \mathrm{M}$-acetic acid (from the preliminary tests, acetic acid gave a $85 \%$ product recovery).

Measurements of CBS activity were based on Mudd et al. ${ }^{(28)}$ and Lambert et $a l^{(27)}$. The following compounds were incubated for $120 \mathrm{~min}$ at $37^{\circ} \mathrm{C}$ in a volume of $400 \mu \mathrm{l}: 100 \mu \mathrm{l}$ of mix reagent (buffer with $1.2 \mathrm{M}$-Tris- $\mathrm{HCl}, \mathrm{pH} 8.3,20 \mathrm{~mm}$ EDTA, $500 \mathrm{~mm}-\mathrm{DL}-\mathrm{Hcy}$ and $0.6 \mathrm{~mm}$-pyridoxal phosphate); $20 \mu \mathrm{l}$ of $50 \mathrm{~mm}-\mathrm{L}-$ serine $3-{ }^{14} \mathrm{C}$ (ARC) at $2500 \mathrm{~Bq}$. The added volume of each tissue extract was adjusted according to its protein concentration, and homogenisation buffer (0.03 mm-potassium phosphate buffer, pH 6.9, 1 mm-EDTA and $1 \mathrm{~mm}$-dithiothreitol) was added to compensate the volume if necessary. After incubation, the reaction was stopped by adding $400 \mu \mathrm{l}$ of $10 \%$ cold TCA, and all samples were centrifuged for $5 \mathrm{~min}$ at $6500 \mathrm{rpm}$. The supernatant fraction $(500 \mu \mathrm{l})$ was pipetted into $20 \mathrm{ml}$ of water. The mixture was eluted to the column containing Dowex ${ }^{\circledR}$ ion exchange resin $\left(50 \mathrm{Wx} 4\left(\mathrm{H}^{+}\right), 200-400\right.$ mesh; Sigma Aldrich) by rinsing consecutively with $18 \mathrm{ml}$ of water, $35 \mathrm{ml}$ of $0.4 \mathrm{M}-\mathrm{HCl}, 10 \mathrm{ml}$ of water and $4 \mathrm{ml}$ of $2 \mathrm{M}-\mathrm{NH}_{4} \mathrm{OH}$. Preliminary tests indicated a recovery of $54 \%$ with $\mathrm{HCl}$ and $\mathrm{NH}_{4} \mathrm{OH}$. Radioactivity of samples was measured in a Packard Tri-Carb liquid scintillation counter after addition of $10 \mathrm{ml}$ of Ultima-Gold ${ }^{\mathrm{TM}}$ reagent (Perkin Elmer, Les Ulis, France). All analyses were done in duplicate, and a blank value obtained from incubation of a heat-inactivated extract was subtracted for each sample. BHMT and CBS activities are expressed as unit (U)/mg protein, where 1 unit is defined as $1 \mathrm{nmol}$ of betaine and serine transformed in 90 and 120 min reaction, respectively.

\section{Amino acid analyses}

Feed protein-bound amino acids. Feed (100 mg) was hydrolysed $\left(23 \mathrm{~h}, 110^{\circ} \mathrm{C}\right)$ with $25 \mathrm{ml}$ of $6 \mathrm{M}-\mathrm{HCl}$ and $12.5 \mathrm{ml}$ of 2-mercaptoethanol. For the analysis of cystine (through cysteic acid measurement), mercaptoethanol was replaced by a solution of $1 \%$ phenol and $0 \cdot 2 \%$ sodium azide. After dilution (1:20), $10 \mu \mathrm{l}$ of the hydrolysed sample were derivatised by adding $70 \mu \mathrm{l}$ of AccQ.Tag buffer (Waters, Guyancourt, France) and $20 \mu \mathrm{l}$ of AccQ.Fluor reagent (6-aminoquinolyl$N$-hydroxysuccinimidyl carbonate) in a $0.5 \mathrm{ml}$ microtube. A diluted (1:25) standard solution of 17 AA (Sigma Aldrich)) was derivatised in the same way. Each sample $(5 \mu \mathrm{l})$ was then analysed by HPLC (column Symmetry C18, $5 \mu \mathrm{m}$, $3.9 \times 150 \mathrm{~mm}$ ) using three mobile phases (AccQ.Tag buffer, $100 \%$ acetonitrile and water, respectively) with a total elution time of $45 \mathrm{~min}$. The AA separations were done using a flow rate of $1 \mathrm{ml} / \mathrm{min}$, and the control temperature was set at $37^{\circ} \mathrm{C}$. The excitation and emission wavelengths in the fluorescence detector were 250 and $395 \mathrm{~nm}$, respectively.

Haemolymph free amino acids. Haemolymph of six shrimp per treatment (from those sampled for the determination of enzyme activity) was collected by puncture between the cephalothorax and the first pair of pleopods using a $1 \mathrm{ml}$ syringe (needle $25 \mathrm{G} 1.59 \mathrm{~cm}, 0.5 \times 16 \mathrm{~mm}$ ). Plasma was obtained following immediate centrifugation $(5 \mathrm{~min}, 5000 \mathrm{~g}$ ) and stored at $-20^{\circ} \mathrm{C}$. Each plasma sample $(100 \mu \mathrm{l})$ was then centrifuged $\left(1 \mathrm{~h} 30 \mathrm{~min}, 2000 \mathrm{~g}, 15^{\circ} \mathrm{C}\right)$ followed by a filtration (filters Amicon-Microcon, YM $100 \mathrm{kd}$ ) to eliminate protein. Samples were then derivatised following the AccQ.Tag method (Waters) and injected into the HPLC column as described previously. AA concentrations are expressed as $\mu \mathrm{mol} / \mathrm{l}$ of haemolymph.

\section{Statistical analysis}

The effects of dietary Met and choline on metabolism and performances were analysed by a two-way ANOVA using Met (adequate, 30\% limiting and 50\% limiting) and choline (adequate or excess) as independent factors (six diets). The effect of Met and cystine dietary levels was analysed by a two-way ANOVA using the Met levels (30 and 50\% limiting) and cystine levels (normal or excess) (four diets). For the amino acid and enzyme analyses, outliers (detected by a scatterplot with box plots) were excluded from the analysis. Outlier and extreme points are described as follows:

$$
\begin{gathered}
\text { Outliers : value }>\mathrm{UBV}+\mathrm{oc} \times(\mathrm{UBV}-\mathrm{LBV}) \text { and value } \\
<\mathrm{LBV}-\mathrm{Oc} \times(\mathrm{UBV}-\mathrm{LBV}) \\
\text { Extremes : value }>\mathrm{UBV}+2 \mathrm{OC} \times(\mathrm{UBV}-\mathrm{LBV}) \text { and value } \\
<\mathrm{LBV}-2 \mathrm{OC} \times(\mathrm{UBV}-\mathrm{LBV})
\end{gathered}
$$

where LBV is the lower value of the box plot (25th percentile), UBV is the upper value of the box plot (75th percentile) and OC is the outlier coefficient (constant 1.5).

For body composition and performances, four replicates per treatment were considered in the analysis, except for diet DEF30 ( $n$ 3). Because the dietary treatments did not affect the hepatic somatic index and hepatic protein concentration, the enzyme activities were compared in term of units/mg 
protein. All analyses were performed using STATISTICA 5.0 software (StatSoft, Inc., Tulsa, OK, USA). Data were analysed by Duncan's multiple range test in the case of a significant effect $(P<0 \cdot 05)$.

\section{Results}

\section{Performances}

The survival (91-98\%) of the shrimp was not affected by the dietary treatments ( $P>0.05$; Tables 3 and 4$)$. Growth parameters and feed efficiency were significantly higher in shrimp fed the excess dietary choline compared with those fed the basal choline diets $(P<0.05$; Table 3$)$. The $30 \%$ Met-limiting diet significantly reduced the DGC (\%) and feed efficiency of shrimp compared with the CTL diet (Table 3). Surprisingly, growth parameters of shrimp fed the $50 \%$ Met-limiting diets were intermediate between those of shrimp fed the CTL and $30 \%$ Met-limiting diets. We observed a significant interaction between Met and choline for individual $\mathrm{N}$ gain $(P<0.05$; Fig. 1). This interaction should be attributed to the fact that the extra choline improved $\mathrm{N}$ gain in shrimp fed the Met-limiting diets but not in shrimp fed the Met-adequate CTL diet. The addition of cystine significantly improved the DGC and feed efficiency of shrimp, irrespective of the level of the Met limitation $(P<0.05$; Table 4$)$. N gains were significantly increased by the extra dietary cystine at both Met levels (30 and $50 \%$ limiting) $(P<0 \cdot 05$; Fig. 1$)$.

\section{Methionine metabolism}

Both BHMT and CBS were found to be active in the hepatopancreas of $P$. monodon shrimp with high intra-treatment variability. BHMT activity was significantly affected by the dietary Met or SAA level (Table 3). The DEF30-fed shrimp had a significantly lower BHMT activity compared with those fed the CTL diet ( $17 v .33 \mathrm{U} / \mathrm{mg}$ protein, respectively). No significant difference in BHMT activity was found between shrimp fed the CTL and DEF50 diets (33 v. $36 \mathrm{U} / \mathrm{mg}$ protein, respectively). Surprisingly, the addition of dietary choline did not significantly affect BHMT activity, although there was a tendency $(P=0 \cdot 126)$ for lower BHMT activity in shrimp fed the excess choline level at the adequate (CTL) and $30 \%$ Met-limiting levels (DEF30) (Table 3). CBS activity was not affected by either the Met or choline level in the diets ( $P>0.05$; Table 3$)$. The activity in hepatopancreas varied from 3 to $7 \mathrm{U} / \mathrm{mg}$ protein, respectively, for DEF30 + CC- and DEF50-fed shrimp. No significant effect of extra dietary cystine could be detected on BHMT or CBS activity $(P>0 \cdot 05$; Table 4$)$.

Free Met, Hcy and serine concentrations in the haemolymph were not significantly affected by any of the dietary treatments, although free Met slightly decreased with the Met-limiting diets (11 and $10 v .14 \mu \mathrm{mol} / 1$ in the CTL diet) and free serine tended to decrease in the haemolymph of shrimp fed the 30\% Met-limiting diet $(P=0.072$; Table 3$)$. Cysteine was not detected by the HPLC technique, which might reflect its very low concentration. Cystine, cysteic acid and taurine concentrations were significantly affected by the dietary Met level, but not by the dietary choline level (Table 3). Concentrations of cystine and cysteic acid were significantly higher in the haemolymph of shrimp fed the CTL diet compared with those fed the DEF30 diet $(3 \cdot 2$ v. $2 \cdot 1 \mu \mathrm{mol} / 1$ for cystine and $8.5 v \cdot 4.5 \mu \mathrm{mol} / 1$ for cysteic acid). Haemolymph taurine concentration was significantly higher with the DEF50 diet compared with the DEF30 diet $(635.5 v .521 .0 \mu \mathrm{mol} / \mathrm{l})$. The addition of cystine to the DEF30 diet increased haemolymph cystine and taurine concentrations in shrimp $(2.2 v .3 .7$ and $523.4 v .732 .3 \mu \mathrm{mol} / 1$, respectively, for cystine and taurine). However, no increase was observed at the $50 \%$ Met deficiency level (Table 4).

\section{Discussion}

Both choline and cystine have a methionine-sparing effect on protein accretion

Due to size-related differences in specific growth rate, with small animals having a higher specific growth rate than the larger ones ${ }^{(29)}$, some authors proposed to use DGC in order
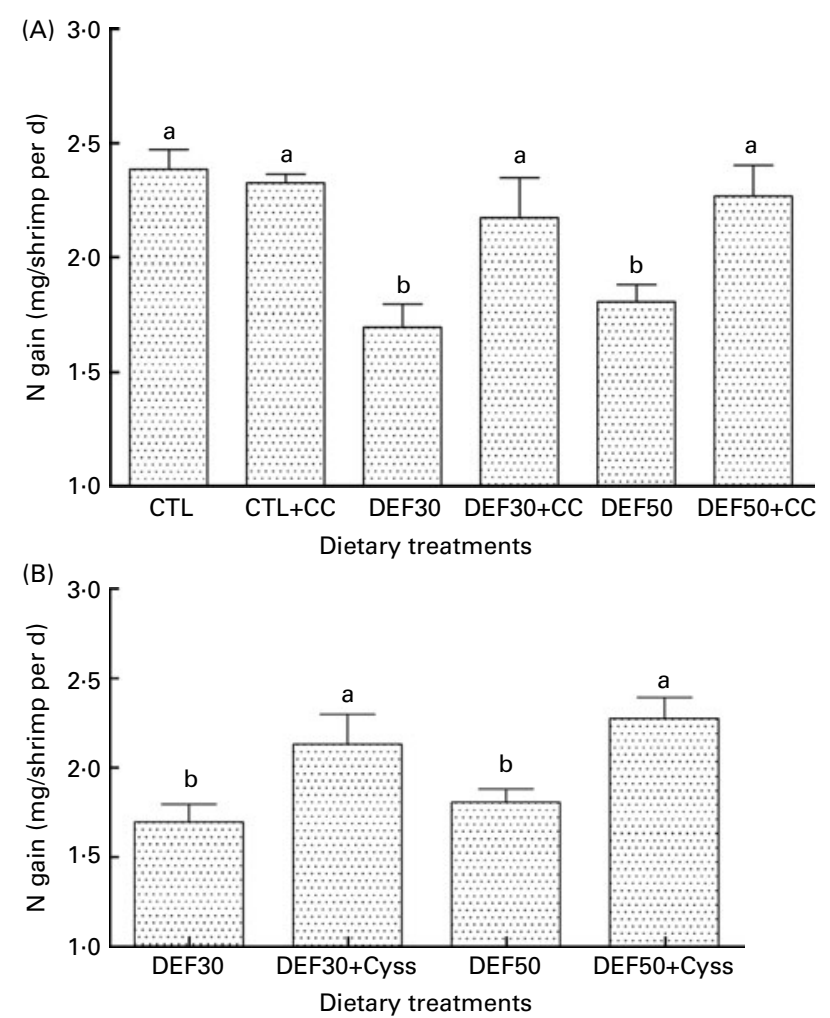

Fig. 1. Effect of dietary levels of choline (A) and cystine (Cyss) (B) on daily individual $\mathrm{N}$ gain $(\mathrm{mg} /$ shrimp per $\mathrm{d}$ ) of juvenile Penaeus monodon fed semipurified diets adequate (control; CTL) or limiting (30 or $50 \%$ ) in sulphur amino acids (SAA; Met + Cyss) during 5 weeks. CC, choline chloride; DEF30, 30\% Met or SAA-limiting diet; DEF50, 50\% Met or SAA-limiting diet. Values are means ( $n 4$ per treatment, except DEF30 where $n 3$ ), with standard errors of the mean represented by vertical bars. ${ }^{\mathrm{a}, \mathrm{b}}$ Mean values with unlike letters are significantly different $(P<0.05$; one-way ANOVA). $P$ values of the two-way ANOVA (Met $\times$ choline) are as follows: MET, $P=0.025$; choline, $P=0.023$; Met $\times$ choline, $P=0.031$. $P$ values of the two-way ANOVA (Met $\times$ Cyss) are as follows: Met, $P=0.215$; Cyss, $P=0.036$; Met $\times$ Cyss, $P=0.313$. 
Table 3. Effect of methionine and choline on growth and metabolic parameters of juvenile Penaeus monodon fed the experimental diets during $35 \mathrm{~d}$ (Mean values with their standard errors)

\begin{tabular}{|c|c|c|c|c|c|c|c|c|c|c|c|c|c|c|c|}
\hline & \multicolumn{15}{|c|}{ Diets } \\
\hline & \multicolumn{2}{|c|}{ CTL } & \multicolumn{2}{|c|}{$\mathrm{CTL}+\mathrm{CC}$} & \multicolumn{2}{|c|}{ DEF30 } & \multicolumn{2}{|c|}{$\mathrm{DEF} 30+\mathrm{CC}$} & \multicolumn{2}{|c|}{ DEF50 } & \multicolumn{2}{|c|}{ DEF50 + CC } & \multicolumn{3}{|c|}{$P$} \\
\hline & Mean & SE & Mean & SE & Mean & SE & Mean & SE & Mean & SE & Mean & SE & Met & $\mathrm{CC}$ & Met $\times \mathrm{CC}$ \\
\hline \multicolumn{16}{|l|}{ Performances* } \\
\hline Survival (\%) & $91 \cdot 7$ & $3 \cdot 2$ & $96 \cdot 7$ & $3 \cdot 3$ & $91 \cdot 1$ & 4.4 & 95 & $3 \cdot 2$ & $96 \cdot 7$ & $3 \cdot 3$ & $98 \cdot 3$ & $1 \cdot 7$ & 0.373 & 0.197 & 0.864 \\
\hline Final body weight $(\mathrm{g})$ & $5 \cdot 7$ & 0.1 & 5.9 & 0.1 & $5 \cdot 1$ & 0.1 & $5 \cdot 6$ & 0.3 & 5.4 & 0.1 & $5 \cdot 8$ & 0.2 & 0.092 & 0.020 & 0.704 \\
\hline Daily growth coefficient $(\%) \dagger$ & 0.82 & 0.05 & 0.93 & 0.01 & 0.62 & 0.04 & 0.79 & 0.05 & 0.73 & 0.04 & 0.84 & 0.06 & 0.009 & 0.003 & 0.786 \\
\hline Apparent feed intake (mg/shrimp per d)‡ & 276 & 8 & 258 & 3 & 245 & 18 & 257 & 20 & 253 & 16 & 303 & 18 & 0.248 & 0.249 & 0.093 \\
\hline Feed efficiency & 0.24 & 0 & 0.29 & 0 & 0.2 & 0 & 0.25 & 0 & 0.23 & 0 & 0.23 & 0 & 0.006 & 0.003 & 0.062 \\
\hline \multicolumn{16}{|l|}{ Enzyme activities (U/mg protein)§ } \\
\hline BHMT & 42 & 8 & $26(7)$ & 5 & 22 & 5 & 13 & 4 & $36(8)$ & 9 & $37(7)$ & 3 & 0.012 & 0.126 & 0.363 \\
\hline CBS & $5(5)$ & 1 & $5(4)$ & 1 & 5 & 2 & $3(5)$ & 1 & 7 & 3 & $4(4)$ & 1 & 0.626 & 0.419 & 0.867 \\
\hline \multicolumn{16}{|l|}{ Free haemolymph amino acids $(\mu \mathrm{mol} / \mathrm{l}) \S$} \\
\hline Methionine & $13 \cdot 6$ & $1 \cdot 1$ & 11.9 & 2 & $10.9(5)$ & 1.5 & $7 \cdot 8$ & 1 & $9 \cdot 7$ & 2.4 & $10 \cdot 0(5)$ & 1.6 & 0.105 & 0.281 & 0.622 \\
\hline Homocysteine & 3.5 & 0.8 & 3.8 & 0.5 & 3.6 & 0.6 & 4.1 & $1 \cdot 2$ & 4 & 0.8 & 3.7 & 0.8 & 0.957 & 0.833 & 0.897 \\
\hline Serine & $46 \cdot 8$ & 8 & 49.7 & 11 & $36 \cdot 8$ & $4 \cdot 8$ & $29 \cdot 1$ & $2 \cdot 3$ & 49 & $4 \cdot 7$ & $48 \cdot 4(5)$ & 11 & 0.072 & 0.769 & 0.772 \\
\hline Cysteine & ND & & ND & ND & ND & ND & ND & ND & ND & ND & ND & ND & & & \\
\hline Cystine & $3 \cdot 1(5)$ & 0.2 & $3 \cdot 2$ & 0.3 & $2 \cdot 2$ & 0.2 & $2 \cdot 0(5)$ & 0.5 & 2.5 & 0.2 & $2 \cdot 7$ & 0.3 & 0.001 & 0.961 & 0.787 \\
\hline Cysteic acid & $9 \cdot 8(5)$ & 1.3 & $7 \cdot 3$ & 1.4 & $5 \cdot 1$ & 0.7 & 3.8 & 0.7 & 4.4 & 1.4 & 4.1 & 1.6 & 0.002 & 0.177 & 0.693 \\
\hline Taurine & 584 & 69 & 629.3 & 37 & 523.4 & 30 & 518.6 & 36 & $597 \cdot 1$ & 20 & 673.9 & 48 & 0.031 & 0.270 & 0.633 \\
\hline
\end{tabular}

CTL, control diet; CC, choline chloride; DEF30, $30 \%$ Met- or sulphur amino acid (SAA)-limiting diet; DEF50, $50 \%$ Met- or SAA-limiting diet; BHMT, betaine-homocysteine methyltransferase; CBS, cystathionine $\beta$-synthase; ND, not detected.

* Values are mean values with their standard errors of four replicate tanks, with exception of treatment DEF30 where only three replicate tanks are considered.

† Daily growth coefficient $(\%):\left(W_{\mathrm{f}}^{(1 / 3)}-W_{\mathrm{i}}{ }^{(1 / 3)} / \mathrm{d}\right) \times 100$, where $W_{\mathrm{i}}$ and $W_{\mathrm{f}}$ are the mean initial and final body weights $(\mathrm{g})$, respectively.

$\ddagger$ Apparent feed intake: $((\mathrm{FG}-\mathrm{FU}) \times(100$ - leaching \%) $) /(N \times 35 \mathrm{~d})$, where $\mathrm{FG}$ is the total feed gift $(\mathrm{g} \mathrm{DM})$, FU is the total amount of uneaten feed $(\mathrm{g} D M)$, leaching \% is the percentage of feed loss after $2 \mathrm{~h}$ immersion in water

$\S$ Values are means of six shrimp haemolymph samples unless noted otherwise (in parentheses). 
Table 4. Effect of methionine and cystine on growth and metabolic parameters of juvenile Penaeus monodon fed the experimental diets during $35 \mathrm{~d}$ (Mean values with their standard errors)

\begin{tabular}{|c|c|c|c|c|c|c|c|c|c|c|c|}
\hline & \multicolumn{11}{|c|}{ Diets } \\
\hline & \multicolumn{2}{|c|}{ DEF30 } & \multicolumn{2}{|c|}{ DEF30 + Cyss } & \multicolumn{2}{|c|}{ DEF50 } & \multicolumn{2}{|c|}{ DEF50 + Cyss } & \multicolumn{3}{|c|}{$P$} \\
\hline & Mean & SE & Mean & SE & Mean & SE & Mean & SE & Met & Cystine & Met $\times$ Cystine \\
\hline \multicolumn{12}{|l|}{ Performances* } \\
\hline Survival (\%) & $91 \cdot 1$ & 4.4 & 95 & $1 \cdot 7$ & $96 \cdot 7$ & $3 \cdot 3$ & $96 \cdot 7$ & 1.9 & 0.231 & 0.509 & 0.509 \\
\hline Final body weight $(\mathrm{g})$ & $5 \cdot 1$ & $0 \cdot 1$ & $5 \cdot 7$ & 0.2 & $5 \cdot 4$ & $0 \cdot 1$ & $5 \cdot 7$ & 0.3 & 0.606 & 0.055 & 0.608 \\
\hline Daily growth coefficient (\%)† & 0.62 & 0.04 & 0.84 & 0.04 & 0.73 & 0.04 & 0.84 & 0.05 & 0.236 & 0.002 & 0.226 \\
\hline Apparent feed intake (mg/shrimp per d)‡ & 245 & 18 & 269 & 4 & 253 & 16 & 284 & 25 & 0.539 & 0.148 & 0.832 \\
\hline Feed efficiency & 0.2 & 0.01 & $0 \cdot 25$ & 0.02 & 0.23 & 0.01 & 0.24 & 0.01 & 0.57 & 0.03 & 0.132 \\
\hline \multicolumn{12}{|l|}{ Enzyme activities (U/mg protein)§ } \\
\hline BHMT & 22 & 5 & $31(5)$ & 13 & $36(8)$ & 9 & $20(5)$ & 9 & 0.906 & 0.756 & 0.2 \\
\hline CBS & 5 & 2 & 7 & 1 & 7 & 3 & $9(4)$ & 1 & 0.368 & 0.227 & 0.991 \\
\hline \multicolumn{12}{|l|}{ Free haemolymph amino acids $(\mu \mathrm{mol} / \mathrm{l}) \S$} \\
\hline Methionine & $10.9(5)$ & 1.5 & $11.7(5)$ & 1.3 & $9 \cdot 7$ & $2 \cdot 4$ & 11.6 & $2 \cdot 2$ & 0.747 & 0.522 & 0.789 \\
\hline Homocysteine & 3.6 & 0.6 & 4.4 & 1 & 4 & 0.8 & 3.6 & 0.7 & 0.778 & 0.835 & 0.48 \\
\hline Serine & $36 \cdot 8$ & 4.8 & $36 \cdot 3$ & 4.5 & 49 & 4.7 & $31 \cdot 2(5)$ & 5.9 & 0.48 & 0.079 & 0.096 \\
\hline Cysteine & ND & & ND & & ND & & ND & & & & \\
\hline Cystine & $2 \cdot 2^{\mathrm{c}}$ & 0.2 & $3 \cdot 7^{\mathrm{a}}(5)$ & 0.2 & $2 \cdot 5^{\mathrm{bc}}$ & 0.2 & $2 \cdot 9^{b}$ & 0.2 & 0.334 & 0 & 0.009 \\
\hline Cysteic acid & $5 \cdot 1$ & 0.7 & $5 \cdot 1$ & 0.9 & 4.4 & 1.4 & $2 \cdot 2$ & 0.5 & 0.069 & 0.246 & 0.268 \\
\hline Taurine & $523 \cdot 4^{b}$ & $30 \cdot 2$ & $732 \cdot 3^{a}$ & 33.2 & $597 \cdot 1^{b}$ & $20 \cdot 2$ & $576 \cdot 9^{\mathrm{b}}(5)$ & $42 \cdot 1$ & 0.211 & 0.007 & 0.002 \\
\hline
\end{tabular}

DEF30, 30\% Met- or sulphur amino acid (SAA)-limiting diet; Cyss, cystine; DEF50, 50\% Met- or SAA-limiting diet; BHMT, betaine-homocysteine methyltransferase; CBS, cystathionine $\beta$-synthase; ND, not detected.

a,b,c Mean values within a row with unlike superscript letters were significantly different $(P<0.05)$.

* Values are means of four replicate tanks (SE), with exception of treatment $D E F 30$, where only three replicate tanks are considered.
†Daily growth coefficient $(\%):\left(W_{\mathrm{t}}^{(1 / 3)}-W_{\mathrm{i}}^{(1 / 3)} / \mathrm{d}\right) \times 100$, where $W_{\mathrm{i}}$ and $W_{\mathrm{f}}$ are the mean initial and final body weights $(\mathrm{g})$, respectively.

‡ Apparent feed intake: $((\mathrm{FG}-\mathrm{FU}) \times(100$ - leaching \% $)) /(\mathrm{N} \times 35 \mathrm{~d})$, where $\mathrm{FG}$ is the total feed gift $(\mathrm{g} \mathrm{DM})$, FU is the total amount of uneaten feed $(\mathrm{g} D \mathrm{DM})$, Leaching\% is the percentage of feed loss after $2 \mathrm{~h}$ immersion in water

(salinity 30 parts per thousand) and $N$ is the average number of shrimp per tank over $35 \mathrm{~d}$.

$\S$ Values are means of six shrimp haemolymph samples unless noted otherwise (in parentheses). 
to compare growth data between studies with fish ${ }^{(30)}$ or crustaceans $^{(31)}$. The present DGC values $(0 \cdot 82-0.93$ in Met adequate treatments) are similar to those found in other studies with shrimp fed semi-purified diets, in $P$. monodon (maximum DGC of $0 \cdot 76-0 \cdot 86)^{(32-34)}$ or $M$. japonicus (maximum DGC of $0.68-0.89)^{(35,36)}$. The growth rate as observed in the present study was also similar to that of $P$. monodon (recalculated DGC of $0 \cdot 75-1 \cdot 18 \%$ ) having, as in the present study, a relatively high initial body weight (approximately $3 \mathrm{~g}$ ) and being fed a practical diet ${ }^{(37)}$.

As anticipated from our previous study on the determination of Met requirements in juvenile $P$. monodon ${ }^{(4)}$, the $30 \%$ SAA (Met and cystine) limitation significantly decreased protein accretion. This reduction in protein accretion $(-29 \%)$ due to the SAA limitation as well as the daily $\mathrm{N}$ gains of the control group is similar to data obtained in our previous study ${ }^{(4)}$. However, it remains unclear why $\mathrm{N}$ gain did not further decrease by the $20 \%$ extra deficiency (DEF50 $v$. DEF30). This contrasts with findings in other growing animals such as chickens ${ }^{(38)}$, pigs ${ }^{(39)}$ or fish ${ }^{(40-42)}$, where a severe Met deficiency induces a higher $\mathrm{N}$ loss than a marginal Met deficiency.

As with vertebrates, shrimp have a choline requirement for maximal weight gain, which seems to vary among shrimp species, being eight times superior in $P$. monodon compared with $M$. japonicus $(0.47 v .0 .06 \% \text {, respectively })^{(43)}$. Since Met and choline share a common role as methyl donor, the requirement for Met is influenced by that for choline and vice versa $^{(23,41)}$. The interactive effect of choline and Met on growth has been examined in only one penaeid shrimp, $M$. japonicus ${ }^{(15)}$. Using a $2 \times 3$ design with two Met concentrations (0.30 and $1.65 \%)$ and three choline levels (0.03, 0.08 and $0 \cdot 14 \%$, the foresaid authors have found that choline in excess (0.14\%) improved the weight gain of $M$. japonicus only when fed the low-Met diet. The present results suggest a similar interaction between choline and Met since extra choline significantly improved protein deposition when added to both Met-limiting diets, but not when added to the Metadequate CTL diet. The latter observation not only validates that the basal Met supply $(0 \cdot 8 \%)$ was appropriate for normal growth in $P$. monodon, but also suggests that the basal choline supply (about $0.3 \%$ ) fulfilled the requirements. This choline level is, however, lower than the requirement value $(0.47 \%)$ previously reported in $P$. monodon ${ }^{(43)}$, possibly because the authors used a low Met level $(0 \cdot 49 \%)$ close to that of the present $50 \%$ Met-limiting diet.

The dietary supplementation of cystine, at both limiting Met levels, increased the $\mathrm{N}$ gain of the shrimp up to that obtained with the CTL. In other words, keeping the total SAA level constant at $1 \cdot 1 \%$ of the diet, while exchanging (on a weight basis) 30 or $50 \%$ of Met by cystine, resulted in a similar protein accretion. Although the sparing effect of cyst(e)ine on Met requirements for protein accretion has not been examined before in shrimp, our data agree with studies in other animal species, showing that cystine can replace about $50 \%$ of Met in growing pigs ${ }^{(21)}$, chicks ${ }^{(18,19)}$ or rainbow trout $^{(16,17)}$. The observation that the $1 \cdot 1 \%$ SAA diets with the cystine:Met ratio of $0.4,0.9$ and 1.6 led to equivalent $\mathrm{N}$ gain in juvenile $P$. monodon, as well as recent results in fish, which reported no reduction in protein accretion when feeding diets low in Met but not in cyst(e)ine (e.g. Atlantic salmon $)^{(6,44)}$, underline the importance of estimating requirements for protein gain in terms of total SAA rather than for Met alone.

\section{Regulation of methionine metabolism by methionine, cystine and choline}

In crustaceans, so far, no study has examined the functionality of the pathways of Met metabolism and the dietary regulation of remethylation (BHMT or MS) and trans-sulfuration (CBS and cystathionase) enzyme activities, both being well documented in mammalian vertebrates ${ }^{(9)}$. The present study is thus the first ever to examine the ability of shrimp to regulate Met utilisation at the biochemical level.

Using the classical methodology developed for mammals ${ }^{(26-28)}$, we demonstrated the presence of enzyme activity for both BHMT and CBS in P. monodon hepatopancreas, the major site for digestive enzyme secretion and nutrient absorption. In rats, activity of BHMT is principally detected in the liver $^{(9)}$, and that of CBS mostly in the liver and pancreas ${ }^{(28)}$. The specific BHMT activities in the present study varied between 13 and $42 \mathrm{U} / \mathrm{mg}$ protein (90 min reaction) and are within the range of those observed in cattle $(17-22 \mathrm{U} / \mathrm{mg}$ protein per $90 \mathrm{~min})^{(27)}$, but two- to eightfold lower than in rats ${ }^{(7,45,46)}$ or chickens ${ }^{(47)}$. Specific CBS activity $(3-9 \mathrm{U} / \mathrm{mg}$ protein) was slightly below the hepatic CBS activity in growing cattle $(15-20 \mathrm{U} / \mathrm{mg} \text { protein per } 60 \mathrm{~min})^{(27)}$ but more than tenfold lower than in the rat liver (with or without Met supply) ${ }^{(26)}$.

The present results show a significant effect of the dietary SAA content on BHMT remethylation activity, being the lowest in shrimp fed the $30 \%$ SAA-limiting diet and back to control levels with the 50\% SAA-limiting diet. Whereas BHMT activity has been reported to be unaffected by a reduction in dietary Met in pigs ${ }^{(24)}$, comparable quadratic BHMT responses have been observed in the liver of cattle ${ }^{(27)}$ and rats ${ }^{(46)}$, following more extreme variations in Met supply (from excessive to quasi-absent), than in the present study (from adequate to highly limiting). Remethylation of Hcy to Met occurs by two pathways, using either BHMT or MS as the catalysing enzyme. Although the relative contribution of both enzymes has been suggested to be equal in the rat liver ${ }^{(11)}$, recent data from broilers indicate that Hcy fluxes through BHMT and MS change according to the dietary SAA level, with an almost equal contribution at adequate SAA supply and a lower relative contribution of BHMT (compared with MS) at excess and limiting SAA supply ${ }^{(48)}$. The latter observation possibly explains the reduced BHMT activity observed in the present study with the 30\% SAA-limiting diet compared with SAA-adequate CTL. Regarding choline, several studies in mammals ${ }^{(24,45)}$ and birds ${ }^{(47)}$ have found that hepatic BHMT activity increases by adding choline to diets either adequate or limiting in Met, consistent with the use of choline-derived methyl groups for remethylation. In contrast, BHMT activity in the present study tended ( $P=0 \cdot 126)$ to decrease in shrimp fed the extra choline at the 
adequate or $30 \%$ limiting SAA supply. That BHMT activity may not be as responsive to dietary choline as concluded previously has recently been underlined in a study with broilers following similar observation as in the present study ${ }^{(22)}$. Moreover, analysis of both remethylation pathways in terms of Hcy fluxes showed that excess choline in chicks (regardless of the dietary SAA level) decreases the relative contribution of BHMT to remethylation while increasing that of $\mathrm{MS}^{(48,49)}$. Several hypotheses may explain the apparent inconsistencies in the effect of choline on the regulation of Hcy remethylation ${ }^{(48)}$. First, an excess of methyl groups may inhibit BHMT due to an excess of dimethylglycine, a by-product of BHMT reaction $^{(9,11,49)}$. Also, serine may be used for the production of more 5-methylenetetrahydrofolates, increasing remethylation through folate-dependent $\mathrm{MS}^{(48)}$.

Following the addition of cystine in both SAA-limiting diets, shrimp did not respond by increasing BHMT remethylation or decreasing CBS activity, which catalyses the first step of trans-sulfuration. This was surprising, as the effect of cysteine on hepatic Met metabolism was earlier found to be related to dietary Met level, with a down-regulation of CBS only in rats fed a low-Met diet with extra cysteine ${ }^{(7,8)}$. Based on these results, we expected the CBS activity to decrease with the addition of dietary cystine, in line with the enhanced protein accretion observed in these shrimps. Hence, the constant low CBS activity, irrespective of the cystine or Met supply, seems to reflect a poor trans-sulfuration, with Met being directed mostly towards protein synthesis. However, metabolic fluxes have previously been reported to be affected by the catalytic constant rate, the enzyme concentration or the substrate concentration ${ }^{(50)}$. This was already observed in the rat liver in which the flow through the BHMT reaction increased while enzyme activity decreased $^{(11)}$. In the present study, the absence of change in haemolymph concentrations of Met and Hcy implies that the pathways controlling intracellular Met/Hcy metabolism were effectively regulated in juvenile $P$. monodon. These observations emphasise the need to undertake complementary studies on the effect of dietary SAA levels on the flux of Hcy through remethylation and trans-sulfuration.

Apart from being needed for protein synthesis, Met and cyst(e)ine are precursors of biologically important S-containing molecules such as glutathione or taurine ${ }^{(9)}$. Among its many physiological functions, taurine plays a major role in cellular osmoregulation ${ }^{(51)}$, which is of particular importance in $P$. monodon and other euryhaline animals living in intertidal ecosystems. In terrestrial vertebrates, taurine is synthesised mostly via cysteine sulphinic acid, involving cysteine dioxygenase and cysteinesulphinate decarboxylase ${ }^{(51,52)}$. However, the capacity for taurine synthesis appears to be species-dependent as illustrated by the dietary taurine requirement in cats, due to a lack of cysteinesulphinate decarboxylase ${ }^{(53)}$. Among teleost species, some debate remains regarding the capacity of some marine fish to synthesise taurine ${ }^{(6,52,54-57)}$. This field of research has importance especially in the context of replacing the fish and shrimp meal (rich in taurine) by plant protein sources (lacking in taurine) in the feeds. Literature on taurine synthesis capacity of crustacean species is scarce. While the freshwater prawn Macrobrachium rosenbergii appears able to cover its taurine requirement by biosynthesis ${ }^{(58)}$, the enhanced growth of $P$. monodon following the addition of taurine to purified diets $(4-8 \mathrm{~g} / \mathrm{kg}$ diet $)$ suggests limited taurine synthesis in $P$. monodon ${ }^{(59)}$. Nevertheless, in the present study, the growth of the shrimp fed diets that were devoid of crystalline taurine was not lower than that of shrimp receiving semi-purified diets with $5 \mathrm{~g} / \mathrm{kg}$ diet of taurine as part of the attractant blend ${ }^{(4)}$. Furthermore, the taurine concentrations in the haemolymph of shrimp in the present study were within the range of values reported before in P. monodon reared at a salinity of $30 \mathrm{~g} / \mathrm{l}^{(60)}$, even with the $50 \%$ SAA-limiting diet. Moreover, the increase in haemolymph taurine concentration following cystine addition to the $30 \%$ Met-limiting diet suggests that $P$. monodon has a capacity to regulate taurine synthesis in relation to dietary cystine levels. However, the role of taurine and the regulatory pathways of taurine synthesis in $P$. monodon, and aquatic crustacean species in general, needs further investigation.

\section{Conclusions}

Our data demonstrate the sparing effect of choline and cystine on Met requirements for protein accretion in juvenile P. monodon, and suggest that growth requirements should be expressed in terms of total SAA rather than Met alone. The present study shows for the first time the existence and functionality of enzymes involved in Met metabolism (i.e. BHMT and CBS) located in shrimp hepatopancreas. BHMT, but not CBS, which had an overall low activity, was found to respond to the dietary SAA deficiency. The addition of choline and cystine to the SAA-limiting diets did not stimulate remethylation by BHMT nor did they down-regulate CBS trans-sulfuration activity. However, the constant Met and Hcy concentrations in the haemolymph, independent from dietary treatment, suggest that the shrimp were able to maintain remethylation/trans-sulfuration equilibrium. Finally, our data suggest the capacity of shrimp to synthesise taurine. However, further research is needed to better understand the sparing effects of choline and cystine on Met requirements and to characterise the pathways regulating taurine synthesis.

\section{Acknowledgements}

The authors acknowledge Frédéric Terrier and Peyo Aguirre for their help during diet manufacturing and Marie Jo Borthaire for her assistance with the laboratory analyses. Special thanks are due to Christian Ramamonjisoa (Aqualma facility) for his technical assistance. L. R. designed the study and did the data analysis. L. R., S. J. K. and I. G. contributed to the drafting of the manuscript. C. V. and L. R. performed the enzymatic analyses. A. S. performed the AA analyses. L. R. and V. R. contributed to the organisation of the study in Madagascar. There are no contractual agreements for the presented data, which might cause conflicts of interest. The authors acknowledge UNIMA and institutional funds from INRA for funding the present study and Agence National de la Recherche et de la Technologie (ANRT; France) for the scholarship to L. R. (CIFRE PhD Research Grant). 


\section{References}

1. FAO (2007) FAO Fisheries Department, Fishery Information, Data and Statistics Unit. FISHSTAT Plus: Universal Software for Fishery Statistical Time Series, version 2.3, 2000.

2. Nguyen TN \& Davis DA (2009) Re-evaluation of total sulphur amino acid requirement and determination of replacement value of cystine for methionine in semi-purified diets of juvenile Nile tilapia, Oreochromis niloticus. Aquacult Nutr 15, 247-253.

3. Davis DA \& Arnold CR (2000) Replacement of fish meal in practical diets for the Pacific white shrimp, Litopenaeus vannamei. Aquaculture 185, 291-298.

4. Richard L, Blanc P-P, Rigolet V, et al. (2010) Maintenance and growth requirements for nitrogen, lysine and methionine and their utilisation efficiencies in juvenile black tiger shrimp, Penaeus monodon, using a factorial approach. Br J Nutr 103, 984-995.

5. Richard L, Vachot C, Brèque J, et al. (2010) The effect of protein and methionine intake on glutamate dehydrogenase and alanine aminotransferase activities in juvenile black tiger shrimp Penaeus monodon. J Exp Mar Biol Ecol 391, $153-160$

6. Espe M, Hevroy EM, Liaset B, et al. (2008) Methionine intake affect hepatic sulphur metabolism in Atlantic salmon, Salmo salar. Aquaculture 274, 132-141.

7. Finkelstein JD, Martin JJ \& Harris BJ (1986) Effect of dietary cystine on methionine metabolism in rat liver. J Nutr $\mathbf{1 1 6}$, 985-990.

8. Finkelstein JD, Martin JJ \& Harris BJ (1988) Methionine metabolism in mammals. The methionine-sparing effect of cystine. J Biol Chem 263, 11750-11754.

9. Stipanuk MH (2004) Sulfur amino acid metabolism: pathways for production and removal of homocysteine and cysteine. Annu Rev Nutr 24, 539-577.

10. Baker DH (2006) Comparative species utilization and toxicity of sulfur amino acids. $J$ Nutr 136, 1670S-1675S

11. Finkelstein JD \& Martin JJ (1984) Methionine metabolism in mammals. Distribution of homocysteine between competing pathways. J Biol Chem 259, 9508-9513.

12. Millamena OM, Bautista-Teruel MN \& Kanazawa A (1996) Methionine requirement of juvenile tiger shrimp Penaeus monodon Fabricius. Aquaculture 143, 403-410.

13. Liou CH \& Yang SD (1994) Dietary methionine requirements of Penaeus monodon. A Paper Presented at the Annual Meeting of Taiwan Fisheries Society December 5-8, Taipei, Taiwan.

14. Teshima S, Alam MS, Koshio S, et al. (2002) Assessment of requirement values for essential amino acids in the prawn, Marsupenaeus japonicus (Bate). Aquacult Res 33, 395-402.

15. Michael FR, Koshio S, Teshima S, et al. (2006) Effect of choline and methionine as methyl group donors on juvenile kuruma shrimp, Marsupenaeus japonicus Bate. Aquaculture 258, 521-528.

16. Walton MJ \& Cowey CB (1982) Methionine metabolism in rainbow trout fed diets of differing methionine and cystine content. J Nutr 112, 1525-1535.

17. Cowey CB, Cho CY, Sivak JG, et al. (1992) Methionine intake in rainbow trout (Oncorbynchus mykiss), relationship to cataract formation and the metabolism of methionine. $J$ Nutr 122, 1154-1163.

18. Graber G \& Baker DH (1971) Sulfur amino acid nutrition of the growing chick: quantitative aspects concerning the efficacy of dietary methionine, cysteine and cystine. J Anim Sci 33, 1005-1011.
19. Sasse CE \& Baker DH (1974) Sulfur utilization by the chick with emphasis on the effect of inorganic sulfate on the cystine-methionine interrelationship. J Nutr 104, $244-251$.

20. Teeter RG, Baker DH \& Corbin JE (1978) Methionine and cystine requirements of the cat. J Nutr 108, 291-295.

21. Chung TK \& Baker DH (1992) Maximal portion of the young pig's sulfur amino acid requirement that can be furnished by cystine. J Anim Sci 70, 1182-1187.

22. Dilger RN, Garrow TA \& Baker DH (2007) Betaine can partially spare choline in chicks but only when added to diets containing a minimal level of choline. J Nutr 137, $2224-2228$.

23. Wu G \& Davis DA (2005) Interrelationship among methionine, choline, and betaine in channel catfish, Icatlurus punctatus. $J$ World Aquacult Soc 36, 337-345.

24. Emmert JL, Webel DM, Biehl RR, et al. (1998) Hepatic and renal betaine-homocysteine methyltransferase activity in pigs as affected by dietary intakes of sulfur amino acids, choline, and betaine. J Anim Sci 76, 606-610.

25. Simon J (1999) Choline, betaine and methionine interactions in chickens, pigs, and fish (including crustaceans). World Poult Sci J 55, 353-374.

26. Finkelstein JD \& Mudd SH (1967) Trans-sulfuration in mammals. The methionine-sparing effect of cystine. J Biol Chem 242, 873-880.

27. Lambert BD, Titgemeyer EC, Stokka GL, et al. (2002) Methionine supply to growing steers affects hepatic activities of methionine synthase and betaine-homocysteine methyltransferase, but not cystathionine synthase. J Nutr 132, 2004-2009.

28. Mudd SH, Finkelstein JD, Irreverre F, et al. (1965) Transsulfuration in mammals: microassays ans tissue distributions of three enzymes of the pathway. J Biol Chem $\mathbf{2 4 0}$, 4382-4392.

29. Kaushik SJ (1998) Nutritional bioenergetics and estimation of waste production in non-salmonids. Aquat Living Resour 11, 211-217.

30. Bureau DP, Kaushik SJ \& Cho CY (2002) Bioenergetics. In Fish Nutrition, pp. 1-53 [JE Halver and RW Hardy, editors]. San Diego, CA: Academic Press.

31. Bureau DP, Azevedo PA, Tapia-Salazar M, et al. (2000) Pattern and cost of growth and nutrient deposition in fish and shrimp: potential implications and applications. In Proceedings of the 5th International Symposium on Aquaculture Nutrition, 19-22 November 2000, Yucatán, Mexico, pp. 111-140 [LE Cruz-Suárez, D Ricque-Marie, M TapiaSalazar, MA Olvera-Novoa and R Civera-Cerecedo, editors]. Mérida, Yucatán, Mexico.

32. Chen HY, Leu YT \& Roelants I (1992) Quantification of arginine requirements of juvenile marine shrimp, Penaeus monodon using microencapsulated arginine. Mar Biol 114, $229-233$.

33. Millamena OM, Bautista-Teruel MN, Reyes OS, et al. (1998) Requirements of juvenile marine shrimp, Penaeus monodon (Fabricius) for lysine and arginine. Aquaculture 164, 95-104.

34. Millamena OM, Teruel MB, Kanazawa A, et al. (1999) Quantitative dietary requirements of postlarval tiger shrimp, Penaeus monodon, for histidine, isoleucine, leucine, phenylalanine and tryptophan. Aquaculture 179, 169-179.

35. Teshima S, Koshio S, Ishikawa M, et al. (2001) Protein requirement of the prawn Marsupenaeus japonicus estimated by a factorial method. Hydrobiologia 449, 293-300.

36. Alam M, Teshima S, Koshio S, et al. (2005) Supplemental effects of coated methionine and/or lysine to soy protein 
isolate diet for juvenile kuruma shrimp, Marsupenaeus japonicus. Aquaculture 248, 13-19.

37. Glencross B, Smith DM, Tonks ML, et al. (1999) A reference diet for nutritional studies of the giant tiger prawn Penaeus monodon. Aquacult Nutr 5, 33-39.

38. Sekiz SS, Scott ML \& Nesheim MC (1975) The effect of methionine deficiency on body weight, food and energy utilization in the chick. Poult Sci 54, 1184-1188.

39. Chung TK \& Baker DH (1992) Methionine requirement of pigs between 5 and 20 kilograms body weight. J Anim Sci 70, 1857-1863.

40. Simmons L, Moccia RD, Bureau DP, et al. (1999) Dietary methionine requirement of juvenile Arctic charr Salvelinus alpinus (L.). Aquacult Nutr 5, 93-100.

41. Kasper CS, White MR \& Brown PB (2000) Choline is required by tilapia when methionine is not in excess. J Nutr 130, 238-242.

42. Ruchimat $\mathrm{T}$, Masumoto $\mathrm{T}$, Hosokawa H, et al. (1997) Quantitative methionine requirement of yellowtail (Seriola quinqueradiata). Aquaculture 150, 113-122.

43. Shiau SY \& Lo PS (2001) Dietary choline requirement of juvenile grass shrimp (Penaeus monodon). Anim Sci 72, 477-482.

44. Sveier H, Nordas H, Berge GE, et al. (2001) Dietary inclusion of crystalline D- and L-methionine: effects on growth, feed and protein utilization, and digestibility in small and large Atlantic salmon (Salmo salar L.). Aquacult Nutr 7, 169-181.

45. Finkelstein JD, Martin JJ, Harris J, et al. (1982) Regulation of hepatic betaine-homocysteine methyltransferase by dietary betaine. J Nutr 113, 519-521.

46. Finkelstein JD, Harris BJ, Martin JJ, et al. (1982) Regulation of hepatic betaine-homocysteine methyltransferase by dietary methionine. Biochem Biophys Res Commun 108, 344-348.

47. Emmert JL, Garrow TA \& Baker DH (1996) Hepatic betainehomocysteine methyltransferase activity in the chicken is influenced by dietary intake of sulfur amino acids, choline and betaine. J Nutr 126, 2050-2058.

48. Pillai PB, Fanatico AC, Beers KW, et al. (2006) Homocysteine remethylation in young broilers fed varying levels of methionine, choline, and betaine. Poult Sci 85, 90-95.
49. Pillai PB, Fanatico AC, Blair ME, et al. (2006) Homocysteine remethylation in broilers fed surfeit choline or betaine and varying levels and sources of methionine from eight to twenty-two days of age. Poult Sci 85, 1729-1736.

50. Stipanuk MH \& Dominy JE Jr (2006) Surprising insights that aren't so surprising in the modeling of sulfur amino acid metabolism. Amino Acids 30, 251-256.

51. Jacobsen JG \& Smith LH (1968) Biochemistry and physiology of taurine and taurine derivatives. Physiol Rev 48, 424-511.

52. Goto T, Matsumoto T \& Takagi S (2001) Distribution of the hepatic cysteamine dioxygenase activities in fish. Fish Sci 67, 1187-1189.

53. Knopf K, Sturman JA, Armstrong M, et al. (1978) Taurine: an essential nutrient for the cat. J Nutr 108, 773-778.

54. Kim SK, Matsunari H, Takeuchi T, et al. (2008) Comparison of taurine biosynthesis ability between juveniles of Japanese flounder and common carp. Amino Acids $\mathbf{3 5}$ $161-168$.

55. Gaylord TG, Teague AM \& Barrows FT (2006) Taurine supplementation of all-plant protein diets for rainbow trout (Oncorbynchus mykiss). J World Aquacult Soc 37, 509-517.

56. Yokoyama M, Takeuchi T, Park GS, et al. (2001) Hepatic cysteinesulphinate decarboxylase activity in fish. Aquacult Res 32, 216-220.

57. Kaushik S \& Luquet P (1977) Study of free amino acids in rainbow trout in relation to salinity changes. 1 . Blood free amino acids during starvation. Ann Hydrobiol 8, 135-144.

58. Smith BR, Miller GC, Mead RW, et al. (1987) Biosynthesis of asparagine and taurine in the freshwater prawn, Macrobrachium rosenbergii (De man). Comp Biochem Physiol Part B 87, 827-831.

59. Shiau SY \& Chou BS (1994) Grass shrimp, Penaeus monodon, growth as influenced by dietary taurine supplementation. Comp Biochem Physiol Part A 108, 137-142.

60. Fang L-S, Tang C-K, Lee D-L, et al. (1992) Free amino acid composition in muscle and hemolymph of the prawn Penaeus monodon in different salinities. Nippon Suisan Gakk $\mathbf{5 8}$, 1095-1102. 